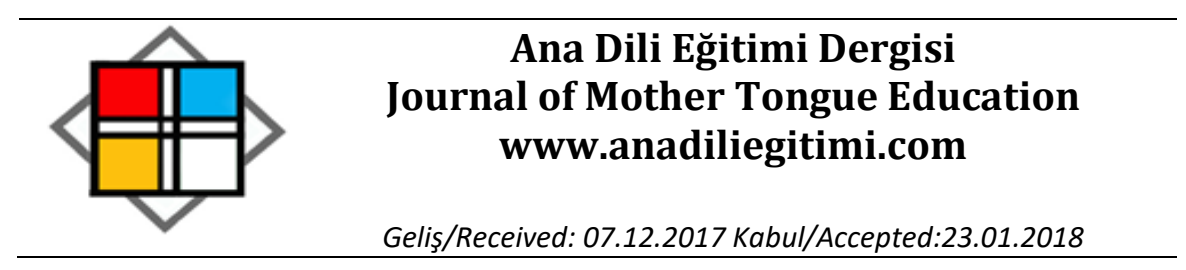

\title{
Çok Katmanlı Okuryazarlık Bağlamında Oyunlaştırmanın Türkçe Öğretim Sürecine Katkısı*
}

\begin{abstract}
Mazhar BAL ${ }^{* *}$
Öz

Bu çalışma, Türkçe öğretim süreciyle oyunlaştırmanın ilişkisini belirlemek amacıyla gerçekleştirilmiştir. Çalışma, nitel araştırma yöntemlerinden örnek olay incelemesi ile desenlenmiştir. Çalışmanın katılımcılarını, Türkçe öğretmenleri oluşturmaktadır. Veri toplama tekniği olarak yarı yapılandııııış görüşme formu kullanılmışıı. Verilerin çözümlenmesinde ise içerik analizi tekniğinden yararlanılmıştır. Araştırmanın verilerinden hareketle oyunlaştırmanın; destekleme, fiziksel etkinlik, dijital, eğlence, somutlaştırma gibi kavramlarla ilişkili olarak algılandığı görülmüştür. Bu açıdan da oyunlaştırmayı daha çok öğretim sürecinin tamamlayıcı olarak algıladıkları sonucuna ulaşılmıştır. Oyunlaştırmanın Türkçe öğretim sürecinde kullanılmasıyla ilgili olarak gereklilik, programa uygunluk ve amaç başlıkları altında görüşler sunmuşlardır. Öğretmenlere göre oyunlaştırmanın, Türkçe öğretim sürecinde kullanılması gerekmektedir çünkü öğrencinin derse karşı ilgisini arttırmakta ve motivasyonunu olumlu yönde etkilemektedir. Ayrıca Türkçe öğretmenlerine göre oyunlaştırma temel dil becerilerinin geliştirilmesine katkıda bulunmaktadır. Öğretmen görüşlerinden hareketle oyunlaştırmanın okuduğunu anlama becerileriyle daha ilişkili olduğu sonucuna ulaşılmıştır.
\end{abstract}

Anahtar Kelimeler: Türkçe öğretim süreci, oyunlaştırma, çok katmanlı okuryazarlık, dijital oyunlar

\section{The Contribution of Gamification in the Context of Multimodal Literacy to the Process of Teaching Turkish}

\begin{abstract}
This study was conducted in order to determine the relation of gamification to the Turkish language teaching process. The study utilized the case study design which is one of the qualitative research methods. Participants of the study were Turkish teachers. A semi-structured interview form was used as the data collection technique. The analysis of the data was done, using the content analysis technique. Based on the results of the research, gamification was perceived to be related to concepts such as support, physical activity, digitalization, entertainment, and concretization. Based on this point of view, it was concluded that the teachers perceived gamification to be more like a complementary element to the teaching process. In terms of the use of gamification in the Turkish language teaching process, the teachers stated their opinions in areas which could be termed as necessity, relevance to the curriculum and purpose. According to the teachers, gamification must be used in the Turkish language teaching process because it increases the students' interest towards the course and affects their motivation positively. Moreover, Turkish language teachers have the opinion that gamification contributes to the development of basic language skills. Based on the teachers' opinions, it was concluded that gamification was related more to reading comprehension skills.
\end{abstract}

Key Words: Turkish language teaching process, gamification, multimodal literacy, digital games

\footnotetext{
* Bu çalışma 28-30 Eylül 2017 tarihinde düzenlenen 10. Uluslararası Türkçenin Eğitimi ve Öğretimi Kurultayı́nın özet kitapçığında "Çok Katmanlı Metin Bağlamında Oyun Teorisinin Temel Dil Becerilerinin Geliştirilmesine Katkısı" adı altında basılmıştır. Alınan eleştiriler doğrultusunda makale haline getirilirken çalışmanın ismi başlıkta görüldüğü şekilde düzenlenmiştir.

** Arş. Gör. Dr., Akdeniz Üniversitesi, Eğitim Fakültesi, Türkçe Eğitimi Ana Bilim Dalı. Antalya. e-posta: balmazhar@gmail.com
} 


\section{Giriş}

Oyun kavramı, geçmişi eskilere dayanan bir anlam çağrıştırabilmektedir. Bu yüzden de insanlık tarihinin başından beri var olan; geleneksel cirit oyunlarından günümüzde dijital oyunlara doğru evrilen (Tuğrul, Ertürk, Özen Altınkaynak ve Güneş, 2014) oyuna dair farklı açıklamalar yapılmıştır. Oyunla ilgili yapılan açıklamalardan (Boratav, 2013; Ergün, 1980; Main ve O'Rourke, 2011; Niko, Valentijn, Arnold ve Huib de, 2016; Partington, 2010; Pieter Van den, 2017; Yalçın ve Aytaş, 2003) hareketle oyunun eğlenceli etkinliklerle öğrenme deneyimleri sunan bir faaliyet olduğu söylenebilir.

Bireyin yaşamında özellikle çocukluk döneminde önemli bir etkinlik olan oyunların eğitim için de önemli bir içerik sağladığı bilinmektedir.Hatta oyunlarla ilgili çalışmalar oyun teorisi adı altında sınırları çizilerek kuramsallaştırılmıştır (Bryan, 2007; Ghic ve Grigorescu, 2014; Vesperman ve Clark, 2016). Son yıllarda da oyunlaştırma adı ile yaygın bir şekilde çalışmalar yapıldığı görülmektedir. Oyunlaştırmanın eğitimde başarıyı arttırmada (Su ve Cheng, 2015) öğrenciye ilgi çekici öğrenme ortamı sunarak motivasyonunu olumlu yönde etkilemede (Alireza, Donald ve Mark Ward, 2014; Cheong, Filippou ve Cheong, 2014; Furdu, Tomozei ve Kose,2017; Marti-Parreno, Mendez-Ibanez ve Alonso-Arroyo, 2016), okul içi ve okul dışı yaşantıyı birleştirmede(Simões, Redondo ve Vilas, 2013), işbirliğini ve etkileşimi arttırmada önemli bir role sahip olduğu yapılan çalışmalarla ortaya koyulmuştur.

Oyunlaştırmanın eğitimde kullanımıyla ilgili Türkiye'deki alan yazına bakıldığında son üç yılda bir artış olduğu görülmektedir. Yapılan çalışmalar daha çok oyunlaştırmanın eğitimde alternatif bir yöntem olarak kullanılabileceği yönündedir (Çağlar ve Kocadere, 2015; Gökkaya, 2014; Güler ve Güler, 2015; Karataş, 2014; Polat, 2014; Sarı ve Altun, 2016; Şahin ve Samur, 2017; Şahin ve Namlı, 2016; Taşkin ve Çakmak, 2017; Yapıcı ve Karakoyun, 2017; Yıldırım, 2016; Yıldırım ve Demir, 2014). Milli Eğitim Bakanlığı tarafından 2017 yılında yenilenen öğretim programlarında da dijital beceriler ve dijital metinler üzerinde önemle durulmaktadır. Bu programlardan birisi de Türkçe Dersi Öğretim Programı (1-8. sınıflar) (2017)'dır. 2017 yılında ilk defa uygulanmaya başlayan programda çok katmanlı metinlere yer verilmiştir. Her ne kadar programda yer verilmese de dijital oyunların, Türkçe derslerinde bir metin türü olarak kullanılmak üzere önerilmesi gerektiği düşünülmektedir. Bu anlamda alanyazındaki çalışmalar önem taşımaktadır.

Alanyazına bakıldığında dijital oyunları ve dijital becerileri ele alan oyunlaştırmaya yönelik tek bir çalışmaya (Genç Ersoy, 2017) rastlanmıştır. Bunun dışında yapılan çalışmalar oyunlaştırmayı dijital ortamdan uzak, dramatizasyona dayalı bir öğretim tekniği olarak ele almıştır (Arıcı, 2006; Kırkkılıç, Kılıç ve Topal, 2005; Sever, 2003; Şimşek ve Topal, 2006). İçinde bulunulan çağın özellikleri, Türkçe Dersi Öğretim Programının (2017) amaçları ve öğrencilerin okul dışı yaşamları göz önünde 
bulundurulduğunda alanyazında oyunlaştırma ile ilgili bir eksiklik olduğu söylenebilir. Bu doğrultuda alanyazında eksik olduğu düşünülen dijital oyunların Türkçe öğretim sürecine katkısının belirlenmesi amaçlanmıştır. Bu amaçtan hareketle aşağıdaki araştırma sorularına cevap aranmıştır:

1. Türkçe öğretmenlerine göre oyunlaştırma ne ifade etmektedir?

2. Oyunlaştırmanın Türkçe öğretim süreciyle ilişkilendirilmesine yönelik Türkçe öğretmenlerinin görüşleri nelerdir?

3. Temel dil becerilerinin geliştirilmesi açısından oyunlaştırmanın önemine yönelik Türkçe öğretmenlerinin görüşleri nelerdir?

\section{Yöntem}

\section{Araştırma deseni}

Araştırma yorumlayııı paradigmaya dayanmaktadır. Süreç nitel araştırma yöntemlerinden örnek olay incelemesi şeklinde desenlenmiştir. Bütüncül tek durum deseni kullanılmıştır. Araştırmanın bu şekilde desenlenmesinin sebebi Türkçe öğretim süreciyle oyunlaştırmanın nasıl ilişkilendirileceği, öğretim sürecine ne gibi katkılarının olacağının bütüncül bir şekilde incelenmek istenmesidir (Creswell, 2013; Glesne, 2013; Merriam, 2013).

\section{Araştırmanın Katılımcıları}

Araştırmanın katılımcılarını, Türkçe öğretmenleri oluşturmaktadır. Katılımcılar seçilirken ölçüt örnekleme tekniğinden yararlanılmıştır. Türkçe öğretmenlerinin dijital oyunlarla ilgili e-twinning projesi yapmaları ölçüt olarak kullanılmıştır. Bu ölçütten hareketle 30 Türkçe öğretmeni (15 kadın, 15 erkek) araştırmanın katılımcılarını oluşturmuştur. Katılımcılara araştırma öncesi sekiz sorudan oluşan bir bilgi formu dağıtılmıştır. Bilgi formundaki ilk dört soru demografik bilgilerden oluşmaktadır. Sonraki dört soru ise doğrudan araştırmanın amacıyla ilişkilidir. Bu sorular "Türkçe dersinde kullanabildikleri teknolojik imkânların varlı̆̆ı", "Türkçe dersinde teknoloji kullanım sıklıkları", "daha önce öğretim sürecinde teknoloji kullanımıyla ilgili eğitim alıp almadıkları" ve "Türkçe dersinde dijital oyunların kullanımıyla ilgili deneyimlerinin olup olmadığı" şeklindedir. Araştırmanın katılımcılarının tümü Türkçe derslerinde kullanılmak üzere etkileşimli tahta, masaüstü bilgisayar ve internet imkânlarına sahip olduklarını belirtmiştir. Beş katılımcı ise (Ö1, Ö3, Ö14, Ö21, Ö25) Türkçe dersinde dizüstü bilgisayar ve tabletlerden yararlandıklarını ifade etmiştir. Türkçe dersinde teknoloji kullanım sıklığı ile ilgili olarak öğretmenlerin hepsi her derste mutlaka oyunlaştırmayı kullandıklarını belirtmiştir. Öğretmenlerin tümü daha önce öğretim sürecini teknolojiyle ilişkilendirme konusunda eğitim aldıklarını söylemiştir. Zaten bu konuyla ilgili olarak araştırmanın katılımcıları belirlenirken da e-twinning projesi yapmaları ölçüt olarak belirlenmiştir. Son olarak öğretmenlerin hepsi Türkçe dersinde daha önce dijital oyunları kullandıklarını ifade etmiştir. Bu deneyimleri gerçekleştirmiş olmaları çalışmanın amacı açısından önem taşımaktadır. Çünkü öğretmenlerin, Türkçe dersiyle 
oyunlaştırmayı ilişkilendirme konusunda doğrudan deneyimlerine dayanarak gerçekçi ve açıklayıcı görüşler sunduğu düşünülmektedir.

\section{Veri Toplama Araçları}

Bu çalışmada veri toplama tekniği olarak yarı yapılandırılmış görüşme formu kullanılmıştır. Yarı yapılandırılmış görüşme formundan hareketle Türkçe öğretim süreciyle oyunlaştırmanın ilişkilendirilmesi konusunda Türkçe öğretmenlerinin görüşleri derinlemesine belirlemeye çalışılmıştır. Bu amaçla da üç farklı yarı yapılandırılmış görüşme formu geliştirilmiştir. Görüşme formu geliştirilirken çalışmanın amacından hareketle sorular geliştirilmiştir. Geliştirilen sorular, kapsam geçerliği açısından değerlendirilmek üzere (Glesne, 2013) uzman görüşüne sunulmuştur. Uzman görüşleri sonrası gerekli düzeltmeler yapılan formun pilot uygulaması yapılmıştır. Pilot uygulama yapılırken araştırmanın katılımcıları ile benzer özelliklere sahip bir grup olmasına dikkat edilmiştir. Pilot uygulamadan gelen dönütler sonucunda yarı yapılandırılmış görüşme formu uygulama için son halini almıştır. Art zamanlı olarak gerçekleştirilen görüşmelerin ilki, Türkçe öğretmenlerinin oyun ve oyunlaştırma algısı üzerine dört sorudan oluşmaktadır. İkinci görüşme formunda Türkçe dersinin ve öğretim programının oyunlaştırmayla ilişkilendirilebilirliğine yönelik beş soru bulunmaktadır. Son görüşme formunda ise oyunlaştırmanın temel dil becerilerinin geliştirilmesine katkısı ile ilgili dört soru yer almaktadır. Görüşmeler bireysel olarak yapılmış ve görüşme ses kayıt cihazı ile kayıt altına alınmıştır.

\section{Verilerin Analizi}

Veriler içerik analizi tekniğinden yararlanılarak çözümlenmiştir. Bu analiz tekniği, soruların açık uçlu olması ve belli bir kuram ya da ya da tematik incelemeye bağlı kalmadan yapılmış olmasından dolayı tercih edilmiştir. Bu bağlamda görüşmelerden elde edilen ses kayıtları nitel analiz programında yazıya aktarılmıştır. Verilerden hareketle öncelikle kodlar belirlenmiştir. O kodlardan hareketle kategoriler oluşturulmuş ve son olarak hepsini kapsayıcı bir temaya ulaşıımıştır. Araştırmanın güvenirliğini sağlamak için iki farklı alan uzmanı tarafından ayrı ayrı kodlamalar yapılmış ve güvenirliğin (Görüş birliği / (Görüş birliği + Görüş ayrılığı) × 100) (Miles ve Huberman, 1994, s. 64) \%90 düzeyinde olduğu belirlenmiştir. Çalışmanın geçerliği için ise aktarılabilirlik, güvenilmeye layık olma, onaylanabilirlik ve inandırıcılık yönünden güçlü olmasına dikkat edilmiştir (Lincoln ve Guba, 1985). Bu amaçla da araştırma sürecinin nasıl desenlendiği ve nelerin amaçlandığı detaylı bir şekilde anlatılmıştır. Böylece başka bir araştırmacı tarafından uygulanabilir olması sağlanmaya çalışılmıştır. Araştırmanın raporlaştırılma sürecinde katılımcıların görüşleri doğrudan alıntılarla verilmiştir.

\section{Bulgular ve Yorum}

Bu bölüm, araştırma soruları temel alınarak üç başlık altında toplanmıştır.

Türkçe Öğretmenlerinin Oyunlaştırma Algısına Yönelik Bulgular ve Yorum 
Çok Katmanlı Okuryazarlık Bağlamında Oyunlaştırmanın Türkçe Öğretim Sürecine Katkısı

Bu bölümde Türkçe öğretmenlerine göre oyun ve oyunlaştırmanın ne ifade ettiğiyle ilgili bulgulara yer verilmiştir. Özellikle oyunlaştırmaya yönelik Türkçe öğretmenlerinin algıları belirlenmeye çalışılmıştır. Türkçe öğretmenlerinin oyun ve oyunlaştırmaya yönelik görüşleri doğrudan atıflarla sunulmuştur. Tablo 1'de Türkçe öğretmenlerinin oyun ve oyunlaştırma ile ilgili görüşlerine yönelik içerik analizi sunulmuştur.

Tablo 1. Türkçe öğretmenlerinin oyun ve oyunlaştırmaya yönelik algıları

\begin{tabular}{llll}
\hline Tema & Kategori & Kod & $f$ \\
\hline Oyunlaştırma & Oyun & Dijital & 20 \\
& & Web 2.0 & 6 \\
& & Dijitalleştirme & 5 \\
& Dijitalle ilisskilendirme & 3 \\
& Oyunlaştırma & Destekleme & 12 \\
& Fiziksel etkinlik & 8 \\
& Dijital & 6 \\
& Eğlence & 4 \\
& Somutlaştırma & 2 \\
\hline
\end{tabular}

Tablo 1'de görüldüğü üzere öğretmen görüşleri iki kategori altında toplam dokuz koddan oluşmaktadır. Bu kategorilerden sıklık değeri en yüksek olan kategori oyundur $(f=34)$; ardından ise oyunlaştırma $(f=32)$ kategorisi gelmektedir. Öğretmenlerin oyun algısına bakıldığında oyun kavramına yönelik dört farklı kod sunulmuştur. Öğretmenlerin sıklıkla oyun kavramını, dijital $(f=20)$ kavramı ile eş tuttukları görülmüştür. Oyun kavramını, dijital kavramı ile nasıl ilişkilendirdiklerine yönelik öğretmen görüşleri şu şekilde yansımıştır:

"Z Kuşağı olarak ifade edilen günümüz çocuklarının, dijital oyunlara olan meraklarını eğitimde araç olarak kullanmak işimizi kolaylaştırılacaktır. Ders işlenişinde yerinde kullanılan dijital oyunlar sınıf hâkimiyetini ve ögrrencilerin derse olan ilgilerini de arttıracaktır. Örneğin eş anlamlı kelimelerin öğretiminde "Cram" web 2.0 aracı gibi flashcardları kullanmak konu pekiştirme ve ders sonu değerlendirme için dikkat çekici ve eğlenceli bir çalışmadır." (Ö3, Yarı Yapılandırılmış Görüşme Formu).

"Etkileşimli tahta, tablet ya da cep telefonları aracılığıyla paylaşılan, bilgiyi ezber düzeyinden çıkarıp eğlenceli bir üretim biçimi haline getiren, sürekli gelişen uygulamalar." (Ö12, Yarı Yapılandırılmış Görüşme Formu).

"Oyun normal oyunlardan farklı olarak daha çok zihnin ön planda olduğu problem çözme becerisine dayanan veya var olan bilgileri sınayan oyunlar aklıma geliyor. Ders içerikli oyunlar için bunu söylüyorum. Tabii ki fare kullanımını beceri olarak kabul etmezsek. Passaparola oyunu gibi bildiklerini hafızasında kalanları bilgisayar tablet veya telefondan işaretlemesi ve bunu belli sürede yapmasını ifade ediyor." (Ö9, yarı yapılandırılmış görüşme formu). 
Yukarıdaki örnek görüşlerden anlaşılacağı üzere öğretmenlerin oyunları dijital birer uygulama saydıkları görülmektedir. Bu uygulamadan kasıtlarının web 2.0 araçları olduğu görüşlerine şu şekilde yansımıştır:

"Konuları pekiştirmek amaçlı bazı web 2.0 uygulamaları." (Ö1, Yarı Yapılandırılmış Görüşme Formu).

"Net ortamında web araçları ile ilgili olan online çalışmalar." (Ö11, Yarı Yapılandırılmış Görüşme Formu).

“Öğrencilere web 2,0 araçlarını kullanarak $Q R$ koda gizleyebilecekleri sorular, atasözü tamamlama oyunları, flash kart hazırlama, kelime avı veya yapboz hazırlayabilecekleri eğitim içerikleri geliştirmeleri için bu tarz oyunlar hazırlatıyorum." (Ö14, Yarı Yapılandırılmış Görüşme Formu).

Öğretmenlerin örnek görüşlerinden de anlaşılacağı web 2.0 uygulamalarını dijitalleşmenin bir aracı olarak görmektedirler. Kimi öğretmenler de bu web 2.0 araçlarını, ders içeriğinin dijital oyunlara dönüştürülmesi konusunda şu görüşleri sunmuştur:

“Oyunları dijital ortama aktarılması. Örneğin satranç; bilgisayar üzerinde oynandığında dijitalleşmiş oluyor." (Ö2, Yarı Yapılandırılmış Görüşme Formu).

“...ders içeriklerinin ya da herhangi bir uygulamanın dijital ortamda oyuna dönüştürülmesidir." (Ö5, Yarı Yapılandııılmış Görüşme Formu).

Yukarıdaki örnek görüşlerden de anlaşılacağı üzere oyunları teknolojiyle ilişkili olarak değerlendiren öğretmenler, oyunlaştırmayla ilgili de farklı görüşler sunmuştur. Bu görüşlerin Türkçe öğretim süreciyle ne yönden ilişkili olduğu ile ilgili görüşler Tablo 1'de yer almaktadır. Türkçe öğretmenlerinin görüşlerinde sıklık değeri en yüksek görüş, oyunlaştırmanın destekleyici $(f=12)$ bir rolü olduğu ile ilgilidir. Buna göre bazı öğretmenler şunları söylemiştir:

"Aklıma ilk gelen şey anlamına göre sözcüklerle yaptığım oyunlaştırma." (Ö4, Yarı Yapılandırıımış Görüşme Formu).

"Dersin işlenmesinde sonra pekiştirmek için passaparola, kim milyoner olmak ister vs. oyunları kullanmak geliyor." (Ö9, Yarı Yapılandırılmış Görüşme Formu).

"Dil öğrenimidir sonuçta, konuşuyor olmak başka o dile hâkim olup doğru kullanmak başka oyunda bunun bir parçası olabilir. En çok kullanılan da yanlış yazılmış kelime bulmak, yazım kurallarını oyunlaştırma, ünlü uyumu kuralıyla oyunlaştırma gibi." (Ö13, Yarı Yapılandırılmış Görüşme Formu).

Örnek görüşlerden de anlaşılacağı üzere, öğretmenler oyunlaştırmayı öğretim sürecinin bir parçası olarak görmektedir. Bu amaçla da bilgi aktarım sürecinin ardından kalıcılığı sağlamak için oyunlaştırmayla desteklemektedir. Oyunlaştırmanın Türkçe öğretmenleri açısından destekleyici işleve sahip bir içerik olarak görülme sebeplerinden birisi eğlenceli $(f=4)$ sayılmasıdır: 
“...daha eğlenceli bir öğrenme ortamı meydana getirmek için yapılan etkinlikler." (Ö1, Yarı Yapılandırılmış Görüşme Formu).

"Çocukların eğlenerek öğrenebileceği, renkli bir ders aklıma geliyor." (Ö15, Yarı Yapılandırılmış Görüşme Formu).

Yukarıdaki örneklerde görüldüğü üzere oyunlaştırmanın eğlenceli bir öğrenme ortamı sağlamasının yanı sıra somutlaştırıı $(f=2)$ olma özelliği de öğretmen tarafından tercih edilmesinin bir diğer sebebidir. Konuyla ilgili bir öğretmen "Anlaşılması biraz zor ya da soyut konuları anlaşılır kılmak." (Ö1, Yarı Yapılandırılmış Görüşme Formu) diyerek, oyunlaştırmayı tercih etme sebebine vurguda bulunmuştur.

Oyunlaştırmanın Türkçe Öğretim Süreciyle Illişkilendirilmesine Yönelik Bulgular ve Yorum

$\mathrm{Bu}$ bölüm, Türkçe öğretmenlerinin öğretim sürecinde oyunlaştırmanın kullanımıyla ilgili görüşlerini içermektedir. Öğretmenler, Türkçe öğretim süreciyle oyunlaştırmayı ilişkilendirme konusunda ne düşündüklerini ifade etmişlerdir. Elde edilen verilerin analizi, çalışmanın geçerliğini güçlendirmek amacıyla öğretmen görüşleriyle desteklenmiştir. Tablo 2'de Türkçe öğretim sürecinde oyunlaştırmanın kullanımıyla ile ilgili öğretmen görüşlerine yönelik içerik analizi sunulmuştur.

Tablo 2. Oyunlaştırmanın Türkçe öğretim süreciyle ilişkilendirilmesine yönelik Türkçe öğretmenlerinin görüşleri

\begin{tabular}{llll}
\hline Tema & Kategori & Kod & $f$ \\
\hline Türkçe öğretim sürecinde oyunlaştırma & Gereklilik & İgi çekici & 24 \\
& & Kalıcılık & 12 \\
& & Okul dışı yaşam & 4 \\
& Ölçme ve değerlendirme & 4 \\
& Programa uygunluk & Beceri & 16 \\
& & Eğitsel & 8 \\
& & Uyguna ve anlatma & 4 \\
& & Dil Bilgisi & 4 \\
& Tematik & 4 \\
& Kısmen & 12 \\
& Kazanımlara yansıtma & 8 \\
& Amaç & Uygun değil & 8 \\
& & Ilgi çekicilik & 8 \\
& Eğlendirme & 4 \\
& Öğrenmeyi kolaylaştırma & 4 \\
\hline
\end{tabular}

Tablo 2'de görüldüğü üzere Türkçe öğretmenlerinden elde edilen verilerde, oyunlaştırmanın öğretim süreciyle ilişkilendirilmesine yönelik üç farklı kategoriye ulaşılmıştır. Gereklilik $(f=64)$, programa uygunluk $(f=56)$ ve amaç $(f=44)$ adı altındaki bu kategoriler, kendi içerisinde farklı kodlara ayrılmıştır. Sıklık değeri en yüksek gereklilik kategorisine bakıldığında, altı farklı bileşenden oluştuğu görülmektedir. Öğretmenler, öğretim sürecinde oyunlaştırmadan yararlanmanın bir gereklilik olduğunu ve bu gerekliliğe gerekçe olarak ise ilgi çekiciliği $(f=24)$ sıklıkla şu şekilde ifade etmişlerdir: 
"Derslerde kullanılacak her türlü oyun öğrenciler için fark yaratacaktır. Dijital oyun görsel olarak öğrencilere daha keyifli geleceği için kullanılması gerektiğini düşünüyorum." (Ö6, Yarı Yapılandırılmış Görüşme Formu).

"Kesinlikle gerekli olduğuna inanıyorum çünkü çocuk oyunda bütün kanalları açık olarak hazır bulunur." (Ö9, Yarı Yapılandırımış Görüşme Formu)

"Her tür oyun oynanmalı. Ama dijital oyunlar öğrencilerin çok daha fazla ilgisini çekmekte." (Ö10, Yarı Yapılandırılmış Görüşme Formu).

"Eğer doğru faydalı ve ilgi çekici oyunlar hazırlanabilirse hem ilgi toplama hem eğlenerek öğrenme amaçlı kullanılabilir. Kısacası gerekli olduğunu düşünüyorum." (Ö13, Yarı Yapılandırılmış Görüşme Formu).

Öğretmenleri yukarıdaki örnek görüşlerine bakıldığında öğrencilerin ilgi ve ihtiyaçları doğrultusunda oyunlaştırmanın öğretim sürecindeki yerine dikkat çekilmiştir. Oyunların, öğretim sürecini ilgi çekici hale getirmesinin de Tablo 2 'de görüldüğü üzere okul dışı yaşam $(f=12)$ koduyla doğrudan bağlantılı olduğu düşünülmektedir. Bu düşünce, Türkçe öğretmenlerinin şu görüşlerine dayanmaktadır:

"Sevsek de sevmesek de, istesek de istemesek de dijital oyunlar öğrenciler için çok önemli hale gelmiştir. Biz eğitmenlerin de bu durumu olumlu yönde kullanması eğitim öğretim açısından önemli kazanımlar elde etmemize sebep olacaktır. Ancak dijital oyunları çok dikkatli bir şekilde kullanmalıyız." (Ö3, Yarı Yapılandırılmış Görüşme Formu).

"Evet, dijital ortamlarla iç içe büyüyen nesle ulaşmanın yollarından biri de onların kullandığı bu yeni dili eğitim ortamına entegre etmektir." (Ö12, Yarı Yapılandırılmış Görüşme Formu).

Oyunlaştırmanın gerekliliği üzerine diğer görüşler ise sıklıkla ölçme ve değerlendirmeye katkı, becerileri geliştirici ve eğitsel olduğu yönündedir. Programa uygunluk kategorisi altındaki kodlara bakıldığında daha çok Türkçe öğretmenlerinin, oyunlaştırmayı programa uygun gördüğü Tablo 2'den anlaşıımaktadır. Türkçe Öğretim Programı ve oyunlaştırmanın uyumuna yönelik olumlu görüşler, anlama ve anlatma becerilerine katkı $(f=16)$, dilbilgisine $(f=8)$, konulara $(f=4)$ ve kazanımlara $(f=4)$ uygun olduğu ile ilgilidir. Neden uygun olduğuyla ilgili öğretmen görüşleri ise şu şekildedir:

"Bence çok uygun. Bir sürü dil bilgisi konuları başta olmak üzere geniş bir yelpazesi olan bir ders. Binlerce oyuna ev sahipliği yapabilir." (Ö15, Yarı Yapılandırılmış Görüşme Formu).

"Sonuçta her şeyi oyunlaştırabiliriz. Cevabı evet ya da hayır olan bir soru bile oyunla sorulabilir."(Ö13, Yarı Yapılandırımış Görüşme Formu).

"Yapılandırmacı yaklaşım dijital oyun kullanımına uygundur." (Ö12, Yarı Yapılandırılmış Görüşme Formu). 
Öğretmenlerin programla oyunlaştırmayı uygun bulduğuna yönelik bu görüşlerin yanı sıra hiç uygun olmadığı yönünde görüşler de bulunmaktadır. Her ne kadar bu görüşler kategori altında en az sıklık gösteren $\operatorname{kod}(f=4)$ olsa da önemli olduğu düşünülmektedir. Türkçe öğretmenlerinin bu olumsuz düşünceleri sekiz numaralı öğretmenin görüşüyle "Sanmıyorum. Müfredatın revize edilmesi gerekir." (Ö8, Yarı Yapılandırılmış Görüşme Formu) şeklinde özetlenebilir.Tablo 2'deki verilere bakıldığında Türkçe öğretmenlerinin oyunlaştırmadan değişik amaçlarla yararlandığı dikkat çekmektedir. Bu amaçların başında öğrencilerin derse karşı ilgilerini çekmek $(f=12)$ gelmektedir. Bununla ilgili olarak aşağıda bir öğretmenin görüşü genel itibariyle ilgi çekme amacını şu şekilde açıklamaktadır:

"Öğrencinin derse olan ilgisini çekmek, dikkatini toplamak ve dersi eğlenceli hale getirmek amacıyla Zondle, Flipquiz, kahoot gibi araçları kullandım." (Ö3, Yarı Yapılandırılmış Görüşme Formu).

Illgi çekicilik amacıyla ilişkili olarak güdüleme $(f=8)$ farklı bir amaç olarak Tablo 2'de gösterilmiştir. Bu amaç, öğretmen görüşlerinde tıpkı ilgi çekicilik amacı gibi öğretim sürecinin başındaki amaçlar olarak gösterilmiştir. Güdüleme amacıyla aynı sıklık değerine sahip eğlendirme $(f=8)$ ve öğrenmeyi kolaylaştırma $(f=8)$ ise amaçlar arasında gösterilmiştir. Türkçe öğretmenlerinin görüşlerinde bu iki koddan, öğretim süreci devam ederken gerçekleştirilmesi düşünen amaçlar olarak söz edilmiştir. Bunlardan farklı olarak ölçme ve değerlendirme $(f=4)$ ile sözcük dağarcığını geliştirme $(f=4)$ oyunlaştırmanın amaçları arasında yer almaktadır.

Temel Dil Becerilerinin Geliştirilmesi Açısından Oyunlaştırmanın Önemiyle ilgili Türkçe Öğretmenlerinin Görüşlerine Yönelik Bulgular ve Yorum

Bu bölümde Türkçe öğretmenlerine göre oyunlaştırmanın temel dil becerilerinin geliştirilmesine katkısıyla ilgili görüşlerine yer verilmiştir. Türkçe öğretmenlerinin okuma, yazma, konuşma ve dinleme becerilerinin oyunlaştırmayla ilişkisine yönelik görüşleri doğrudan atıflarla sunulmuştur. Tablo 3'de Türkçe öğretmenlerinin temel dil becerileri ile oyunlaştırma arasındaki ilişkiye yönelik görüşlerinin içerik analizi sunulmuştur.

Tablo 3. Türkçe öğretmenlerinin oyun ve oyunlaştırmaya yönelik algıları

\begin{tabular}{llll}
\hline Tema & Kategori & Kod & $f$ \\
\hline Temel Dil Becerileri ve Oyunlaştırma & Okuma & Olumlu & 24 \\
& & Hızlı okuma & 12 \\
& & Geribildirim & 4 \\
& & Kısmen & 4 \\
& & İlgi çekicilik & 4 \\
& & Görsel okuma & 12 \\
& Yazma & Olumlu & 12 \\
& & Kısmen & 4 \\
& & Iliş̧isiz & 4 \\
& & Güdümleme & 4 \\
& İlgi çekicilik & Değişken & Metin oluşturma
\end{tabular}




$\begin{array}{lll}\text { Dinleme } & \text { Yönerge } & 16 \\ & \text { Illgi çekicilik } & 12 \\ \text { Odaklanma } & 12 \\ \text { Seslendirme } & 4 \\ \text { Kilmiyorum } & 4 \\ \text { Kınuşma } & \text { Kısmen } & 24 \\ & \text { Etkileşim } & 8 \\ \text { Olumlu } & 4 \\ & \text { Değişken } & 4\end{array}$

Tablo 3'ten de anlaşılacağı üzere sıklık değeri en yüksek kategori okumadır ( $f=52$ ). Bunu sırasıyla yazma $(f=48)$, dinleme $(f=48)$ ve konuşma $(f=40)$ becerileri izlemektedir. Sıklık değeri en yüksek olan oyunlaştırmanın okuma becerisiyle ilişkisine yönelik Türkçe öğretmenlerinin görüşleri şu şekildedir:

"Dijital oyunları belki de en çok okuma becerilerini geliştirmede kullanıyorum. Yarışmalar da, yazdıkları masalların okunmasında büyük katkı sağladığını düşünüyorum." (Ö3, Yarı Yapılandırılmış Görüşme Formu).

"Katkı sağlayacağını düşünüyorum. Çünkü dijital ortamda okuma ortamı zenginleştirilebiliyor." (Ö5, Yarı Yapılandırılmış Görüşme Formu).

"Okumadan kendisinin bir beceri geliştiremediğinin farkına varacaktır." (Ö6, Yarı Yapılandırılmış Görüşme Formu).

"Okuma becerileri olumlu etkilenir diye düşünüyorum. Çünkü dijital oyunlarda yönergeleri okuyacakları için okuma becerilerinde gelişme olabileceği fikrindeyim." (Ö7, Yarı Yapılandırılmış Görüşme Formu).

Yukarıdaki örnek olumlu görüşlerin yanı sıra öğretmenler oyunlaştırmanın, hızlı okuma $(f=12)$, geribildirim $(f=4)$, ilgi çekicilik $(f=4)$ ve görsel okumayı güçlendirme $(f=4)$ açılarında da okuma becerisine katkıda bulunduğunu belirtmiştir. Öte yandan "Oyun yönergeleri, uyarılar gibi yazılar öğrencilerin okuma-anlama becerilerini, çok az destekler." (Ö14, Yarı Yapılandırılmış Görüşme Formu) görüşünde olduğu gibi okuma eğitimi üzerinde düşük düzeyde katkısı olduğunu belirten öğretmenler de $(f=4)$ bulunmaktadır.

Yazma beceri alanıyla ilgili olarak da Tablo 3'te yedi ayrı kod göze çarpmaktadır. Bu kodlardan olumlu özellik taşıyanlar güdümlü yazma $(f=4)$, ilgi çekiciliği sağlama $(f=4)$ ve metin oluşturmadır $(f=4)$. Türkçe öğretmenlerine göre oyunlaştırma, yazma becerisine şu yönden olumlu katkıda bulunmaktadır:

"Hazırlayacağı dijital oyunla kurgu ve olay olması gerektiğinden, yazarken bunları düşünmesi gerekecektir." (Ö6, Yarı Yapılandırımış Görüşme Formu). 
"Yazma öğrenciler için sıkıı bir etkinliktir. Dijital oyunlarda klavye kullanımından dolayı el yazısı becerilerinde gelişme sağlayacağını düşünmüyorum." (Ö7, Yarı Yapılandırılmış Görüşme Formu).

"Eğitim sitelerinde hazırlanmış olan karışık metin, kelime ve heceleri kullanarak anlamlı kelimeler, metinler ve cümleler yapmalarını isteyen oyunların öğrencinin yazma becerisini oldukça olumlu etkilediğini tecrübelerimle gördüm ve önemsiyorum." (Ö10, Yarı Yapılandırılmış Görüşme Formu).

"ilkokul düzeyinde bakıldığında, oyunlar üzerinden gidilerek yazma becerilerini geliştirmeye yönelik yazma çalışmaları yapılabilir." (Ö1, Yarı Yapılandırılmış Görüşme Formu).

Yukarıdaki örnek görüşlerden de anlaşılacağı üzere oyunlaştırma, yazma becerisini geliştirmede daha çok güdüleyici bir işleve sahiptir. Özellikle yazma becerisi geliştirilirken öğretim sürecinin öğrenciye uygun hale getirilmesinde önemli bir rol üstlendiği görülmektedir. Öte yandan oyunlaştırmanın, yazma becerisine herhangi bir katkısı olmadığı $(f=8)$ ya da kısmen $(f=16)$ katkısı olduğu yönünde görüşler de dikkat çekmektedir. Özellikle yazma becerisiyle oyunlaştırma arasında ilişki kurulamayacağını Ö4 şu sözleriyle özetlemektedir:

"Dijital oyunların daha çok düşünme, iletişim, ifade yeteneğini ön plana çıkaracağını düşünüyorum. Yazma yönünde olumlu veya olumsuz bir etki olacağını düşünmüyorum." (Ö4, Yarı Yapılandırılmış Görüşme Formu).

Bir diğer kategori olan dinlemeyle ilgili beş farklı kod bulunduğu Tablo 3'te görülmektedir. Tablodaki kodlarda ilk dikkat çeken ilgi çekicilik kodudur $(f=12)$. Daha önceki verilerde olduğu gibi oyunlaştırmanın dinleme becerisine de ilgi çekicilik yönünden katkı sağladığı görülmektedir. Bununla birlikte dinleme kategorisi altında sıklık değeri en yüksek olan kod, yönerge $(f=16)$ 'dir. Yönerge kodu ve dinleme becerisi arasındaki ilişkiye yönelik öğretmen görüşleri şu şekilde gösterilebilir:

"Kurallar öğrenciye okunuyor ve uygulaması isteniyorsa anlama ve dinleme konusunda iyi bir alıştırma diye düşünüyorum." (Ö10, Yarı Yapılandırılmış Görüşme Formu).

"Örneğin metnin içerisine yerleştirilecek interaktif butonlarla metnin önceden dinlenilen bölümlerine ait sorular ve cevapları ile metnin daha dikkatli dinlenmesi sağlanabilir." (Ö13, Yarı Yapılandırılmış Görüşme Formu).

"Oyunların yönergeleri sesli olarak belirtildiğinde dinleme becerisini kısmen destekleyebilir. Dinleme anlama becerisi için amaçlı dinleme yapılması gerekmektedir ve bu yönü ile Türkçe dersindeki dinleme metinleri yetersizdir. Dinleme metinleri içerisinde ses efektlerinin de yer alması gerekmektedir." (Ö14, Yarı Yapılandırılmış Görüşme Formu). 
Yukarıda da görüldüğü üzere öğretmenler için oyunlaştırma, yönergeler sayesinde dinleme becerisine önemli bir katkıda bulunmaktadır. Burada yönergeler, öğrencilerin algılarını açmada bir değişken olarak gösterilmektedir. Yönergelerin yanı sıra oyunlaştırmanın dinleme becerisine, odaklanma $(f=12)$ ve seslendirme $(f=4)$ açısında da olumlu katkıda bulunduğu ifade edilmektedir. Özellikle odaklanma ile ilgili öğretmen görüşleri şu şekilde yansımıştır:

"Dikkat süresini artırıyor, aktif katılım sağlıyor." (Ö5, Yarı Yapılandırılmış Görüşme Formu).

"Dijital oyunlarda aşamalı olarak düşündüğümüzde dinlediğini tespit etme oyunu kullanılırsa ve bunu değerlendirme yapılırsa çocuk tekrar dinleme ihtiyacı hissedecek ve daha sonraki çalışmalarda metnin tamamını daha dikkatli dinleyecektir." (Ö9, Yarı Yapılandırılmış Görüşme Formu).

"Oyun sayesinde daha dikkatli ve sessiz dinleyeceklerdir. Dinleme kurallarına tam uyum göstereceklerdir." (Ö15, Yarı Yapılandırılmış Görüşme Formu).

Türkçe öğretmenlerinin oyunlaştırmanın odaklanma açısından dinleme eğitimine katkıda bulunduğu ile görüşlerin önemli olduğu düşünülmektedir. Öğretim süreci açısından bakıldığında, oyunlaştırmanın dinleme gibi ölçme ve değerlendirmesi zor bir becerinin kontrol edilmesini kolaylaştırabileceği görülmektedir. Öğretmen görüşlerinden elde edilen son kategori ise konuşmadır. Konuşma becerisi ile ilgili dört farkı koda ulaşımıştır. Bu kodlar içerisinde sıklık değeri en yüksek olan kısmen $(f=24)$ cevabına yönelik öğretmen görüşleri şu şekilde gösterilebilir:

"Bu çok fazla bir oranda olmayabilir. Oyun genelde görsel, işitsel olarak etkindir. Konuşma becerilerini çok etkilediğini düşünmüyorum." (Ö1, Yarı Yapılandırılmış Görüşme Formu).

"Konuşma beceri açısından etkisi diğer becerilere oranla az olacağını düşünüyorum. Çünkü konuşma becerisi için dijital ortam pek uygun değildir." (Ö2, Yarı Yapılandırılmış Görüşme Formu).

"Kendi düşüncelerini rahatlıkla ifade edebilmelerini sağlayacak dijital oyunlar bulunmaktadır. Ancak konuşma becerilerini geliştirmek amaçı geleneksel oyunların daha etkili olduğunu düşünüyorum. Tekerleme söyleme, sayışma, resim yorumlama, izlediği bir filmi ya da yaşadığı bir olayı anlatma, kulaktan kulağa gibi etkinliklerin daha uygun olduğunu düşünüyorum." (Ö3, Yarı Yapılandırılmış Görüşme Formu).

“Dijital ortamın konuşma becerisine çok katkısı olacağını düşünmüyorum. Uygulamaya göre değişebilir belki ama öğrenciler bu ortamda konuşma becerisini çok kullanmayacak ya da zaman kaybetmemek açısından kısa cümlelerle anlaşma çabasında olacaktır." (Ö12, Yarı Yapılandırılmış Görüşme Formu). 
Çok Katmanlı Okuryazarlık Bağlamında Oyunlaştırmanın Türkçe Öğretim Sürecine Katkısı

"Oyun genelde görsel, işitsel olarak etkindir. Konuşma becerilerini çok etkilediğini düşünmüyorum. Öğrenci bu oyunda seslendirme yapma durumunda bırakılırsa kısmen konuşma becerisini desteklemiş olur." (Ö14, Yarı Yapılandırılmış Görüşme Formu).

Yukarıdaki görüşlerden anlaşılacağı üzere öğretmenler, konuşma becerisini karşıııklı iletişimle ya da yüz yüze görüşme şeklinde algılamaktadır. Bu yüzden de dijital ortamda gerçekleştirilecek oyunların yüz yüze sosyal etkileşimde olduğu gibi konuşma becerisine hizmet edemeyeceğini belirtmektedirler. Öğretmenlerin çoğunun bu görüşlerine karşın Tablo 3'te de görüldüğü üzere oyunlaştırmanın konuşma becerisi üzerine etkisiyle ilgili şunları söyleyen de olmuştur:

"Özellikle oyunlaştırma aşamasında birbirleri ile iletişimlerinin artacağını düşünüyorum."

(Ö8, Yarı Yapılandırılmış Görüşme Formu).

"Takım halinde oynanıyorsa öğrencilerin konuşup birbirlerini anlamaları gerekmektedir.

ifade oyun süresince anlaşılır olmalı ve grup üyeleri iletişimi en üst seviyede gerçekleştirmek durumundadırlar." (Ö10, Yarı Yapılandııımış Görüşme Formu).

Yukarıdaki görüşlerden de anlaşılacağı üzere sıklık değeri düşük olsa da öğretmenler konuşma eğitimi açısından oyunlaştırmanın etkileşimi arttırdığını belirtmişlerdir. Burada ifade edilen etkileşimle ilgili olarak öğretmenlerin karşılıklı ilişkiden çok grup halinde iletişimi kastettiği düşünülmektedir.

\section{Sonuç, Tartışma ve Öneriler}

Araştırmanın bulgularından hareketle öğretmenlerin oyunlaştırmayı, doğrudan bilginin paylaşımı ya da aktarılması olarak görmediği söylenebilir. Türkçe öğretmenlerine göre oyunlaştırma, edinilen bilgilerin tamamlayıcısı ya da pekiştiricisi işlevine sahiptir. Zaten alanyazındaki çalışmalarda ilgili bilginin ya da öğretilecek içeriğin tamamımın aktarılmasının oyunlaştırmayla gerçekleştirilemeyeceğini vurgulamaktadır (Barlow ve Fleming, 2016; Bruder, 2015; Çeker ve Özdamlı, 2017; Kim, 2015; Kolb ve Kolb, 2009; Monterrat, Lavoué ve George, 2017). Bu açıdan da Türkçe öğretmenlerinin oyunlaştırma algılarının alanyazınla uyumlu olduğu söylenebilir.

Bulgularda da görüldüğü üzere öğretmenler, Türkçe öğretim sürecinde oyunlaştırmanın kullanımıyla ilgili gereklilik, kullanım amacı ve programa uygunluk açısından görüşler sunmuştur. Türkçe öğretmenlerine göre oyunlaştırmanın kullanılması bir gerekliliktir. Çünkü oyunlaştırma özellikle öğrenciler açısından öğretim sürecini ilgi çekici hale getirmektedir. Araştırmanın bu sonucu alanyazında farklı çalışmaların sonuçlarıyla (Adèle ve Marlien, 2015; De Marcos, Garcia-Lopez ve Garcia-Cabot, 2016; Furdu, Tomozei ve Köse, 2017; Nicholson, 2012) benzerlik göstermektedir. Öte yandan Hanus ve Fox (2015)'un çalışmasının sonucuyla uyuşmamaktadır. Çünkü onlara göre, oyunlaştırma öğrencilerin sınav başarılarını olumsuz etkilemektedir. 
Gereklilikle ilgili olarak bir başka olumlu bulgu ise oyunlaştırmanın kalıcı öğrenmeyi sağladığı ve öğrencilerin okul dışı yaşamlarıyla ilişki kurduğu yönündedir. Özellikle okul dışı yaşamla ilişki kurma konusunda oyunlaştırmayla ilgili bulgular önem taşımaktadır. Çünkü bu durum öğretmenlerin, okul dışı yaşamla ilişkiyi sağlama konusunda bir sorunla karşı karşıya olduklarının ve bu sorun için çözüm önerisi aradıklarının göstergesi olduğu söylenebilir. Oyunlaştırmanın okul içi ve okul dışı yaşantıyı birleştirdiğine yönelik sonu, Huang ve Soman (2013)'ın ve Ketyi (2016)'nin çalışmaları tarafından da desteklenmektedir. Bununla birlikte Türkçe öğretmenleri, oyunlaştırmanın ölçme ve değerlendirmeyi kolaylaştırdığı için kullanılması gerektiğini belirtmişlerdir. Hiçbir Türkçe öğretmeni, oyunlaştırmanın öğretim sürecinde kullanılmasının gerekli olmadığına dair görüş belirtmemiştir. Bu durumun teorik bilgilerden çok öğretmenlerinin deneyimlerinin sonucunda duyulan memnuniyetten olduğu söylenebilir. Çünkü oyunlaştırmanın Türkçe öğretim sürecinde kullanılmasının gerekliliğine yönelik öğretmen görüşlerinin, kullanım amacına yönelik görüşlerle de doğrudan ilişkili olduğu görülmektedir. Oyunlaştırmayı ne amaçla kullandıklarına dair deneyimlerinden bahseden öğretmenler, kullanım amaçlarına yönelik değişik görüşler sunmuşlardır. Oyunlaştırmanın gerekliliği ile ilgili bulgular göz önünde bulundurulduğunda öğretmenlerin oyunlaştırmanın gereğini öğretim sürecinde yerine getirdikleri söylenebilir.

Oyunlaştırmanın Türkçe öğretim programıyla uygunluğuna yönelik bulgulara bakıldığında, öğretmenlerin görüşlerinin farklılaştığı görülmektedir. Oyunlaştırmanın gerekliliği konusunda olumlu anlamda görüşler sunan öğretmenlerin, programla ilişki söz konusu olduğunda olumsuz görüşleri devreye girmiştir. Yapılan çalışmalarda da (Buckley, Doyle ve Doyle, 2017; Dichev, Dicheva, Angelova ve Agre, 2014; Gunter, Campbell, Braga, Racilan ve Souza, 2016; Lajord, 2016; Stanley, 2012)oyunlaştırmanın dil öğretim programına dahil edilmesinin genel anlamda olumlu etkide bulunacağı ortaya koyulmuştur. Bu açıdan da araştırmanın bu sonucu, alanyazındaki benzer çalışmaların sonuçlarıyla uyuşmamaktadır. Çünkü ilgili çalışmalarda programın, oyunlaştırma önünde engel olduğuna dair herhangi bir görüşe rastlanmamıştır. Öğretmenlerin oyunlaştırmanın programla uyumsuzluğuna dair bulgularına bakıldığında, Türkçe öğretim sürecinde oyunlaştırmayı programdan bağımsız bir şekilde dâhil ettikleri anlaşılmaktadır. Başka bir ifadeyle öğretmenlerin olumsuz görüşlerinden, Türkçe öğretim programının oyunlaştırmayı öğretim süreciyle ilişkilendirmede bir engel olarak görüldüğü anlaşılmaktadır. Öğretmenlerin bu görüşlerinin 2006 Türkçe Öğretim Programına göre sundukları düşünülmektedir. Çünkü Milli Eğitim Bakanlığı, Türkçe Öğretim Programını yenilemiştir. Eski programda dijital beceriler ve bunlarla ilişkili metin türlerine pek yer verilmiyordu (MEB, 2006). Bu yüzden de öğretmenler, programı merkeze aldığımızda oyunlaştırmayı Türkçe öğretim sürecine ilişkilendirmede sorun yaşamış olabilirler. Yenilenen Türkçe Dersi Öğretim Programı (1-8. Sınıflar)’nda çok katmanlı metinler, bilgilendirici ve öyküleyici metinler arasında yerini 
almıştır (MEB, 2017). Program henüz tüm sınıflarda uygulamaya geçmediği için öğretmenlerin programla oyunlaştırmanın ilişkisine yönelik olumsuz görüşlerinin değişebileceği düşünülmektedir.

Oyunlaştırmanın temel dil becerileriyle ilişkisine yönelik bulgulara bakıldığında, dinleme becerisi dışında diğer üç beceri alanıyla ilgili olumsuz görüşler olduğu görülmektedir. Bu durum, diğer üç beceriye hiç katkıda bulunmadığını göstermemektedir. Çoğunluğun olumlu görüş sunduğu dikkate alındığında, olumsuz görüş sunan Türkçe öğretmenlerinin okuma, yazma ve konuşma eğitimi ile oyunlaştırmayı ilişkilendirmede eksiklikleri olduğu söylenebilir. Dinleme eğitimiyle ilgili bulgulara tekrar dönülecek olursa Türkçe eğitimi açısından önemli olduğu düşünülmektedir. Çünkü dinleme eğitimi gerek becerinin kazandırılması gerekse ölçme değerlendirme açısından zor bir beceridir. Oyunlaştırmanın dinleme becerisine değişik yönlerden katkıda bulunduğu Stanley (2012)'in araştırmasında da ortaya koyulmuştur.

Genel olarak beceri alanları açısından bakıldığında anlama becerilerinin oyunlaştırmayla daha ilişkili olduğu sonucuna ulaşılmıştır. Anlatma becerileri açısından ise anlama becerilerine göre daha fazla öğretmenin ilişki kuramadığı sonucuna ulaşılıştır. Özellikle konuşma becerisi ile ilgili olumsuz ve belirsiz görüşler dikkat çekmektedir. Alanyazında yapılan çalışmalarda oyunlaştırmanın yazma becerisiyle (Ana Carolina, Jacqueline Pimentel, Carmen Silvia Motta ve Heloísa Helena Motta,2016; El Tantawi, Alhumaid ve Sadaf, 2016; Griffiths, 2017) ve konuşma becerisiyle (Ketyi, 2016; Schrier, 2014) ilişkilendirildiğinde olumlu sonuçlara ulaşıldığı görülmüştür. Bu yönden araştırmanın bulgularıyla örtüşmemektedir. Öğretim sürecinin tamamlayıcı olarak bakıldığında yazma ve özellikle konuşma becerisi ile oyunlaştırma arasında ilişki kurulmasında zorlanılmasının çelişkili olduğu düşünülmektedir. Üstelik beceriler açısından bakıldığında gerek becerinin gözlemlenmesi gerekse ölçme ve değerlendirme açısından özellikle dinlemeye göre konuşma ve yazma becerilerinin daha kolay yerine getirildiği bilinmektedir.

Araştırmanın sonuçlarından hareketle Türkçe Öğretim Programının çok katmanlı okuryazarlık açısından oyunlaştırmanın kullanımına uygun hale getirilmesi gerekmektedir. Özellikle hem bilgilendirici hem de öyküleyici metin türleri içinde dijital oyunlara verilmelidir. Teknoloji konusunda eğitime yapılan yatırımların önemli olduğu tartışıımaz bir gerçektir. Uygulayıcı olarak öğretmenlerin, teknoloji konusunda eğitimleri yeterli olmadığı sürece yapılan yatırımların tek başına sorunları ortadan kaldırmayacağı ya da eğitimde modernleşmeyi sağlayamayacağı da bilinmektedir. Bu yüzden Türkçe dersi için öğretmenlerin teknolojik, pedagojik ve alan bilgisi eğitimlerine önem verilmesi gerektiği düşünülmektedir.

\section{Kaynaklar}

Adèle, B., \& Marlien, H. (2015). A teacher tablet toolkit to meet the challenges posed by 21st century rural teaching and learning environments. South African Journal of Education, 35(4), 01-19. doi:10.15700/saje.v35n4a1218 
Alireza, T., Donald, L., \& Mark Ward, S. (2014). Insights from massively multiplayer online role playing games to enhance gamification in education. Journal of Systemics, Cybernetics And Informatics, 12 (4), 69-78.

Ana Carolina, S., Jacqueline Pimentel, T., Carmen Silvia Motta, B., \& Heloísa Helena Motta, B. (2016). Games as a measure of reading and writing generalization after computerized teaching of reading skills. Psicologia: Reflexão E Crítica, 29, 3-12. doi:10.1186/s41155-016-0039-3.

Arıcı, A. F. (2006). Türkçe öğretiminde kullanılan strateji-yöntem ve teknikler. Atatürk Üniversitesi Sosyal Bilimler Enstitüsü Dergisi, 7(1), 299-308.

Barlow, T., \& Fleming, B. (2016). A science classroom that's more than a game. Teaching science: The Journal ofthe Australian Science Teachers Association, 62(2), 31-37.

Boratav, P.N. (2013). 100 Soruda Türk Folkloru. Ankara: Bilgesu Yayıncılık,.

Bruder, P. (2015). Game on: gamification in the classroom. Education Digest, 80(7), 56-60.

Bryan C., M. (2007). Using game theory and the bible to build critical thinking skills. The Journal of Economic Education, 38(2):160-164.

Buckley, P., Doyle, E., \& Doyle, S. (2017). Game on! students' perceptions of gamified learning. Journal of Educational Technology \& Society, 20(3), 1-10.

Cheong, C., Filippou, J., \& Cheong, F. (2014). Towards the gamification of learning: Investigating student perceptions of game elements. Journal of Information Systems Education, 25(3), 233-244.

Creswell, J. W. (2013). Nitel araştırma yöntemleri (Çev. Ed. M. Bütün ve S. B. Demir). Ankara: Siyasal Kitabevi.

Çağlar, Ş., \& Kocadere, S.A. (2015). Çevrimiçi öğrenme ortamlarında oyunlaştırma. Journal of Educational Sciences \& Practices, 14(27), 83-102.

Çeker, E., \& Özdaml, F. (2017). What "Gamification" is and what it's not. European Journal of Contemporary Education, 6(2), 221-228. doi:10.13187/ejced.2017.2.221.

David D., Y. (2015). Gamification in thoracic surgery education: A slam dunk?. The Journal of Thoracic and Cardiovascular Surgery, 150(5),1038-1039. doi:10.1016/j.jtcvs.2015.08.004

De Marcos, L., Garcia-Lopez, E., \& Garcia-Cabot, A. (2016). On the effectiveness of game-like and social approaches in learning: Comparing educational gaming, gamification \& social networking. Computers \& Education, 95, 99-113. doi:10.1016/j.compedu.2015.12.008

Dichev, C., Dicheva, D., Angelova, G., \& Agre, G. (2014). From gamification to gameful design and gameful experience in learning. Cybernetics and Information Technologies, 14(4), 80-100.

El Tantawi, M., Alhumaid, J., \& Sadaf, S. (2016). Using gamification to develop academic writing skills in dental undergraduate students. European Journal of Dental Education, doi:10.1111/eje.12238 05.12.2017 tarihinde http://onlinelibrary.wiley.com/doi/10.1111/eje.12238/epdf adresinden erişildi.

Ergün, M (1980). Oyun ve oyuncan üzerine. Milli Eğitim Dergisi, 1 (1),102-119.

Furdu, I., Tomozei, C., \& Kose, U. (2017). Pros and cons gamification and gaming in classroom. Broad Research in Artificial Intelligence and Neuroscience, 8(2), 56-62.

Genç Ersoy, B. (2017). Türkçe dersinde oyunlaştırmanın ilkokul öğrencilerinin söz varlığına ve motivasyonlarına etkisi.Eskişehir:Anadolu Üniversitesi, Eğitim Bilimleri Enstitüsü, Yayımlanmamış Doktora Tezi.

Ghic, G., \& Grigorescu, C. J. (2014). Applications of games theory in analyzing teaching process. Procedia-Social and Behavioral Sciences, 116, 3588-3592.

Glesne, C. (2013). Nitel araştırmaya giriş (Çev. A. Ersoy ve P. Yalçınoğlu). Ankara: Anı Yayıncılık.

Gökkaya, Z. (2014). Yetişkin eğitiminde yeni bir yaklaşım: oyunlaştırma/a new approach of adult educatıon: dramatızatıon. Hasan Ali Yücel Egitim Fakültesi Dergisi, 11(1), 71-84. 
Griffiths, B. (2017). A card trick for Improving writing skills and attendance. Primus, 1-10. doi:10.1080/10511970.2017.1350228. $02.122017 \quad$ tarihinde http://www.tandfonline.com/doi/full/10.1080/10511970.2017.1350228 adresinden erişildi.

Gunter, G. A., Campbell, L. O., Braga, J., Racilan, M., \& Souza, V. V. S. (2016). Language learning apps or games: An investigation utilizing the retaın model. Revista Brasileira de Linguística Aplicada, 16(2), 209-235.

Güler, C., \& Güler, E. (2015). Çevrimiçi öğrenme ortamlarında oyunlaştırma: Rozet kullanımı. Eğitim ve Öğretim Araştırmaları Dergisi, 4(3), 125-130.

Hanus, M. D., \& Fox, J. (2015). Assessing the effects of gamification in the classroom: A longitudinal study on intrinsic motivation, social comparison, satisfaction, effort, and academic performance. Computers \& Education, 80, 152-161. doi:10.1016/j.compedu.2014.08.019

Huang, W. H. Y., \& Soman, D. (2013). Apractitioner's guide to gamification of education. research reports series, behavioural economics in action. Toronto: Rotman School of Management, University of Toronto.

Karataş, E. (2014). Eğitimde oyunlaştırma: Araştırma eğilimleri. Ahi Evran Üniversitesi Kırşehir Eğitim Fakültesi Dergisi, 15(2),315-333.

Ketyi, A. (2016). From mobile language learning to gamification: an overlook of research results with business management students over a five-year period. Porta Linguarum, 45-60. 05.12. 2017 tarihinde http://www.ugr.es/ portalin/articulos/PL_monograph1_2016/art_4.pdf adresinden erişildi.

Kırkkılıç, H. A., Kılıç, Y., \& Topal, Y. (2005). Oyunlaştırma yönteminin dil öğretiminde yeri, önemi ve bazı ingiliz araştırmacıların bu yöntemle ilgili tespitleri. Atatürk Üniversitesi Kazım Karabekir Eğitim Fakültesi Dergisi,12,6-18.

Kim, B. (2015). Chapter 1: The popularity of gamification in the mobile and social era. Library Technology Reports, 51(2), 5-9.

Kolb, A. Y., \& Kolb, D. A. (2009). The learning way meta-cognitive aspects of experiential learning. Simulation \& Gaming, 40(3), 297-327.

Lajord, R. K. (2016). The Gamified Classroom:" It has been different, because we know what we are talking about". Norvey: UiT Norges arktiske universitet, Master's thesis.

Lincoln, Y.S. ve Guba, E.G. (1985). Naturalistic Inquiry. Beverly Hills, CA: Sage.

Main, S., \& O'Rourke, J. (2011). "New directions for traditional lessons": Can handheld game consoles enhance mental mathematics skills? Australian Journal of Teacher Education, 36(2), 43-55.

Marti-Parreno, J., Mendez-Ibanez, E., \& Alonso-Arroyo, A. (2016). The use of gamification in education: a bibliometric and text mining analysis. Journal of Computer Assisted Learning, 32(6), 663-676. doi:10.1111/jcal.12161

MEB. (2006). Illköğretim 6-8. sınıf Türkçe öğretim programı. Ankara: Talim Terbiye Kurulu

MEB. (2017). Türkçe dersi öğretim programı (1-8. Sınıflar). Ankara: Talim Terbiye Kurulu

Merriam, S. B. (2013). Nitel araştırma desen ve uygulama için bir rehber (Çev. S. Turan). Ankara: Nobel Yayıncılık.

Miles M., \& Huberman, M. (1994). An expanded sourcebook qualitative data analysis (2nd. Ed.). CA: Sage Publications.

Monterrat, B., Lavoué, É., \& George, S. (2017). Adaptation of gaming features for motivating learners. Simulation \& Gaming, 48(5), 625-656. doi:10.1177/1046878117712632

Nicholson, S. (2012). A User-centered theoretical framework for meaningful gamification. Paper presented at Games+Learning+Society 8.0, Madison, WI. 
Niko, V., Valentijn, V., Arnold, V., \& Huib de, R. (2016). Player experiences and behaviors in a multiplayer game: Designing game rules to change interdependent behavior. International Journal of Serious Games, 3(4). doi:10.17083/ijsg.v3i4.150

Partington, A. (2010). Game literacy, gaming cultures and media education. English Teaching: Practice and Critique, 9(1), 73-86.

Pieter Van den, H. (2017). Book review: the post-9/11 video game: a critical examination. Press Start. 4(1), 6568.

Polat, Y. (2014). Bir vaka incelemesi: Oyunlaştırma yöntemi ve Ingilizce öğrencilerinin motivasyonu üzerine etkisi. Mersin: Çağ Üniversitesi, Yayınlanmamış Yüksek Lisans Tezi.

Sarı, A., \& Altun, T. (2016). Oyunlaştırma yöntemi ile işlenen bilgisayar derslerinin etkililiğine yönelik öğrenci görüşlerinin incelenmesi. Turkish Journal of Computer and Mathematics Education, 7(3), 553-577.

Schrier, K. (2014). Learning, Education and Games. Volume One: Curricular and Design Considerations. ETC Press. 05.12.2017 tarihinde http://repository.cmu.edu/cgi/viewcontent.cgi?article=1028\&context=etcpress adresinden erişildi.

Sever, S. (2003). Türkçe öğretiminde yeni yapılanma çalışmaları. Türklük Bilimi Araştırmaları, 13(13), 27-38.

Simões, J., Redondo, R. D., \& Vilas, A. F. (2013). A social gamification framework for a K-6 learning platform. Computers In Human Behavior, 29(2), 345-353. doi:10.1016/j.chb.2012.06.007

Stanley, G. (2012). Language teaching and learning online digital games and gamification. 05.12.2017 tarihinde http://www.tesol-spain.org/uploaded_files/files/Graham-Stanley.pdf adresinden erişildi.

Su, C., \& Cheng, C. (2015). A mobile gamification learning system for improving the learning motivation and achievements. Journal Of Computer Assisted Learning, 31(3), 268-286. doi:10.1111/jcal.12088

Şahın, M. C., \& Namlı, N. A. (2016). Gamıfıcatıon and effects on students'scıence lesson achıevement. International Journal on New Trends in Education \& Their Implications (IJONTE), 7(1),41-47.

Şahin, M , Samur, Y . (2017). Dijital çağda bir öğretim yöntemi: Oyunlaştırma. Ege Eğitim Teknolojileri Dergisi, 1(1), 1-27. Retrieved from http://dergipark.gov.tr/eetd/issue/29867/306559

Şimşek, T., \& Topal, Y. (2006). Türkçe eğitiminde drama ve özgün uygulama örnekleri. Atatürk Üniversitesi Sosyal Bilimler Enstitüsü Dergisi, 7(1), 277-298.

Taşkin, N., \& Çakmak, E. K. (2017). Öğrenci merkezli öğrenme ortamlarında oyunlaştırmanın alternatif değerlendirme amaçlı kullanımı.Bartin Üniversitesi Eğitim Fakültesi Dergisi, 6(3), 1227-1248.

Tuğrul, B., Ertürk, H. G., Özen Altınkaynak, Ş., \& Güneş, G. (2014). Oyunun üç kuşaktaki değişimi. The Journal of Academic Social Science Studies, 27, 1-16.

Vesperman, D. P., \& Clark, C. H. (2016). Game theory in the social studies classroom.The Social Studies, 107(6), 194-199, DOI: 10.1080/00377996.2016.1214901

Yalçın, A. ve Aytaş, G. (2003). Çocuk Edebiyatı.Ankara: Akçağ Yayınları.

Yapıcı, İ. Ü., \& Karakoyun, F. (2017). Gamification in biology teaching: A sample of kahoot application. Turkish Online Journal of Qualitative Inquiry, 8(4),396-414.

Yıldııım, ì. (2016). Oyunlaştırma temelli öğretim ilke ve yöntemleri dersi öğretim programının geliştirilmesi, uygulanması ve değerlendirilmesi. Gaziantep: Gaziantep Üniversitesi, Eğitim Bilimleri Enstitüsü, Yayımlanmamış Doktora Tezi.

Yıldırım, I., \& Demir, S. (2014). Oyunlaştırma ve eğitim. International Journal of Human Sciences, 11(1), 655-670.

\section{Extended Summary Introduction}

It is known that games, which are an important activity in the life of an individual, especially during childhood, also provide an important content for education. In this context, theoretical terms such as game 
theory and playing have emerged. In recent years, studies on gamification and game based learning have been seen to be important. Because gamification made positive contributions to the student achievement, to the lesson, to the collaboration, and to the interaction. It has been observed that studies on gamification in Turkey have increased in the last three years. In the renewed Turkish Curriculum (2017), digital skills and multimodal texts come to the forefront. However, there are no digital games in these texts. It is thought that digital games should be taken as a text type of the program. Also it said to be a lack of concern with the dramatization in literature. Therefore, it is thought that it is necessary to study the relation of digital games with the Turkish teaching process in the context of gamification.

\section{Method}

The aim of the research is to determine the contribution of digital games to Turkish language teaching process. It has been examined under three headings. The first is about what Turkish language teachers think about gamification. Secondly, it is determined what Turkish language teachers think about how to associate gamification with the Turkish language teaching process. Finally, it is examined the views of Turkish language teachers regarding the importance of gamification in terms of the development of language arts. The study was designed as a case study from qualitative research methods. The participants of the study consist of 30 Turkish language teachers ( 15 female, 15 male). When participants were selected, e-twinning project related to digital games was used as a criterion. In this study, semi-structured interview form was used as data collection technique. Three different semi-structured interview forms have been developed in order to determine the opinions of Turkish languge teachers in depth regarding the relation of gamification with Turkish language teaching process. The datas were resolved using the content analysis technique.

Results

The findings of the study were reported under three headings. In the first part, Turkish language teachers' findings about the perception of gamification are included. The opinions of Turkish language teachers are composed of a total of nine codes under two categories. Among these categories, the highest frequency category is game $(f=34)$; followed by gamificationcategory $(f=32)$. When teachers' perception of game was examined, four different codes were presented for the concept of game. Teachers have often seen the concept of game equal to the concept of digital $(f=20)$. In the second chapter, findings related to the connection of gamification with Turkish language teaching process are found. In the data obtained from the Turkish language teachers, three different categories have been reached for associating the gamification with the teaching process. These categories under the name of necessity $(f=64)$, programa suitability $(f=56)$ and purpose $(f=$ 44) are divided into different codes within themselves. It is seen that there are six different composites when the category of necessity with the highest frequency value is considered. Teachers showed that gamification is a necessity in the teaching process and that the reason for this is to be interesting $(f=24)$. In the last part, the opinions of Turkish language teachers about the importance of gamification in terms of development of language arts have been included. On the basis of the obtained data, the highest frequency category is readingskill $(f=52)$. This is followed by writing $(f=48)$, listening $(f=48)$ and speaking $(f=40)$ skills respectively.

From the findings of the research, it has been reached that the teachers do not see gamification as direct sharing or transfer of knowledge. According to Turkish teachers, gamification has the function of complementing or reinforcing the acquired knowledge. According to Turkish language teachers, it is a necessity to use gamification. This is because the gamification makes interesting the teaching process for the students. Another positive finding regarding the necessity is that gamification provides a parmenent learning and that students relate to their out of school life. No Turkish language teacher has stated that it is not necessary to use gamification in the teaching process. It is seen that the views of the teachers towards the suitability of the gamification with the Turkish curriculum are different. It has been achieved that Turkish language teacher has negative thoughts about the relationship gamification with the Turkish curriculum. It appears that there are negative opinions about the other three skill areas besides the listening skill related to the language arts of gamification.In general, it is the result that comprehension skills are more related to gamification. In terms of comprehension skills, the result is that more teachers can not relate than narrative skills. Especially negative and unclear opinions about speaking skill are remarkable. 